\title{
戦後の大規模郊外住宅地開発と新住宅市街地開発事業の特質に関する研究 A STUDY ON CHARACTERISTIC OF BIG RESIDENTIAL SUBURB AND THE JAPANESE NEW TOWN ACT DEVELOPMENT
}

\author{
小川知弘*, 塩崎賢明** \\ Tomohiro OGAWA and Yoshimitsu SHIOZAKI
}

\begin{abstract}
The large-scale residential quarter development which exceeds 50ha is done 374 cases. As for these residential quarters it is many in Tokyo and Osaka periphery. Japanese Newtown Act have made 49 Newtown. Japanese New town Act's law has been given expropriation right. Expropriation right was used 24.areas. Japanese New town Act's law because planned characteristic is strong.
\end{abstract}

Keywords : New Town Development, Japanese Newtown Act's, Expropriation, Planned characteristic, 大規模郊外住宅地開発、新住宅市街地開発法、土地収用、計画性、

\section{1. 研究の背景と目的}

\section{1-1. 研究の背景}

わが国における大規模郊外住宅地開発（以下大規模開発）は、明 治末期〜大正期に㧍ける大阪近郊や東京近郊などでの鉄道会社など によるものを噙矢とする。但し、今日ではこれらの戦前郊外住宅地 のほとんどは高級住宅街と化しており、一般的な住宅地と考えるこ とは難しい。戦後の大規模開発は、1960 年代の大都市圈への急速な 人口流入を受けて、一気に本格化することになる。特に、最初の本 格的大規模ニュータウンである千里ニュータウンの成功は、その後 各地に大規模ニュータウン開発が引き起こされるきっかけともなっ ている。

これらの大規模開発に関する研究は、個別のニュータウン開発及 び開発後の変遷について数多くなされている。例えば千里ニュータ ウンについては、片寄注1)が建設過程についての研究を行っており、 住田ら注 ${ }^{2}$ は開発過程と開発後の課題についてまとめている。また、 大規模郊外住宅地の全体的な状㳘については、高橋泩 3)による首都 圈大規模ニュータウン注 4) の形成に関する研究や三好注 5)による近 畿圈の大規模ニュータウンにおける居住者意識に関する研究などが ある。大規模郊外住宅地の全体像に関して扱った研究としては小川 ら注 ${ }^{6}$ ) による新住宅市街地開発事業による住宅団地にお㧍斫隣七 ンターの変遷に関する研究がある。しかしながら、新住事業を含む
大規模郊外住宅地開発の実態や変遷などについて全体的に取り扱っ た研究はみられない。

\section{1-2. 研究の目的}

戦後日本の大規模開発のなかで、新住宅市街地開発事業（以下新 住事業）は、計画性の強さという点において、きわだった特徵を持 っている。そこで、本研究では、第一に戦後の大規模開発の全体的 な特質を明らかにし、第二に大規模開発において指導的モデルであ った新住事業がどのような特質を持っていたのかを明らかにするこ とを目的とする。

\section{1-3. 研究の方法}

研究の方法は以下の通りである。最初にわが国における大規模開 発の全体像を明らかにするために、国土交通省土地・水資源局土地 政策課資料、新版宅地開発便覽掲載の資料注 7)、宅地開発ハンドブッ ク掲載の資料注 8) 及び各都道府県へのヒアリングから、1950 年代以 降の $50 \mathrm{ha}$ 以上の公的な住宅地開発を抽出した。次に、抽出した大 規模開発の地域性・規模などについて分析を行った。新住事業の特 性を明らかにするために、開発地の地域的分布、規模、開発理由、 開発時期などについて分析を行った。

なお、大規模郊外住宅地の定義は、住宅地全体の開発面積が $50 \mathrm{ha}$ 以上の公的な新規住宅地開発とした。このような定義に至った理由 は、日本におけるニュータウン法ともいえる新住宅市街地開発法(以

\footnotetext{
* 神戸大学大学院自然科学研究科

博士後期課程 総合政策修

** 神戸大学大学院工学研究科 教授 $\cdot$ 工博

Graduate School of Science and Technology, Kobe University, M. Policy Studies

Prof., Graduate School of Engineering, Kobe University, Dr. Eng.
} 
下新住法）に基づく住宅団地が「一住区以上で建設された住宅団地」 と定義されており、新住団地のうち、最も面積の小さいグループが 約 $50 \mathrm{ha}$ 注9) で開発されていることからである。

\section{1-4. 新住法の特色と変化}

1960 年代に入ると、大規模ニュータウン開発の必要性が急速に高 まり、三大都市圈を中心に大規模住宅団地の開発一向けた動きが一 気に加速した。そのような中で、大阪府企業局が千里丘陵に建設を 開始した千里ニュータウンにおいて、建設途上における技術的・法 律的な要請が、か权てから存在していた“日本におけるニュータウ ン法制定”を求める動きを後押しして、新住宅市街地開発法が制定 されることとなった。新住法による開発第 1 号は、千里ニニータウ ンのうちの 6 住区であった注 10)。

新住法の特質としては

(1) 土地収用権の付与。

(2) 施行者の限定。

(3) 公共施設も含めた一体的開発。

(4) 転売禁止規制。

(5) 建築条件付分譲

の 5 点が挙げられる。これらの特質に関する根拠は以下の通りであ る。(1)については、「新住宅市街地開発事業につき都市計画法第 69 条の規定により適用される土地収用法の規定により土地又は権利が 収用される場合において、…収用を請求することができる。」（新住 法第 34 条 4 項) と規定されており、(2)について「新住宅市街地開 発事業は、地方公共団体及び地方住宅供給公社のほか、この法律に 特に定める者に限り、施行することができる。」(新住法第 6 条) と されている。(3について、新住事業を「宅地の造成、造成された宅 地の処分及び宅地とあわせて整備されるへき公共施設の整備に関す る事業並びにこれに附帯する事業」(新住法第 2 条) と定めている。 (4)については、10 年間の転売規制がかけられている（新住法第 32 条)。(5については、新住法第 31 条において、「建築物を建築す心゙ き宅地を譲り受けた者は、その譲受けの日の翌日から起算して五年 以内注 11) に、処分計画で定める規模及び用途の建築物を建築しなけ ればならない。としている。

新住法は、1964 年に施行されたが、この段階では住宅地開発に特 化した内容であり、住宅地以外の用途としては、道路・公園緑地・ 公共公益施設などのみが認められており、オフィス等を導入するこ とは認められていなかった。このため、新住団地のほとんどが住宅 団地としての機能に特化しており、イギリスなどのニュータウンに 見られる職住近接型とは別種の形態となっていったといえる。その 後、都市への人口流入に伴う住宅地不足と宅地開発圧力はおちつき、 生活水準の上昇と共に、質の高い住宅地や職住近接などが社会の要 求となってきた 1980 年代に入ると、新住団地も職住近接などが求 められるようになった。そのような背景から、1986 年に新住法は改 正され、新住団地内に企業のオフィス等の立地を認める特定業務施 設地区制度や、分譲における条件の緩和注 $\left.{ }^{12}\right)$ が認められることにな った。

\section{2. 大規模郊外住宅地開発の特徵}

\section{2-1. 開発の概要}

大規模開発を行うための主な手法としては、開発許可制度による
公的団地の建設 (以下公的一般) - 一団地の住宅施設建設 -土地区画 整理事業（以下区画整理）・新住宅市街地開発事業（以下新住事業） の 4 種類が挙げられる。これらの手法のうち、土地を事業者が買収 してから事業を行うのが、公的一般・一団地の住宅施設建設・新住 事業の 3 手法であり、換地によって事業を行うのが区画整理である。 なお、土地の収用権が与えられているのは新住法のみである。

また、2006 年 4 月現在における公的な大規模住宅地開発の主体 としては、都道府県・市町村 - 都道府県住宅供給公社 - 市町村住宅 供給公社・都市再生機構注 13) ・日本勤労者住宅協会などがある。

1950 年代以降の $50 \mathrm{ha}$ 以上の住宅地開発は、総計 374 件注 14)、計 画人口約 600 万人にのぼり、北海道や兵庫県などの人口に匹敵する 巨大な人口注 15) が大規模郊外住宅団地に居住している。

\section{2-2. 地域特性}

大規模開発の件数を都道府県別にみてみると、最も件数が多いの が千葉県の 45 件で、次いで兵庫県の 33 件、埼玉県の 29 件、茨城 県が 25 件、北海道が 24 件と続いている。また、大規模開発が全く 行われなかった県が、山梨県・福井県・島根県・徳島県の 4 県であ る。これらの 4 県はいずれも県全体の人口が 100 万人未満であり、 大都市圈に属していない点などが共通している。開発件数は $1 \sim 4$ 件の府県が最も多く、次いで $5 \sim 9$ 件が多い。10 件以上の大規模開 発が行われていたのは 12 都道府県であった。また、大都市圈注 16 ) と地方部を比較すると、地方部の県では開発件数が 5 件未満が半数 以上を占めているのに対して、大都市圈では開発件数が 10 件以上 の都道府県が過半数を占めている。ここからも、大規模開発が大都 市圈中心に行われていたことが指摘できるが、一方で地方部におい ても大規模開発自体は活発に行われていた。（図 1)

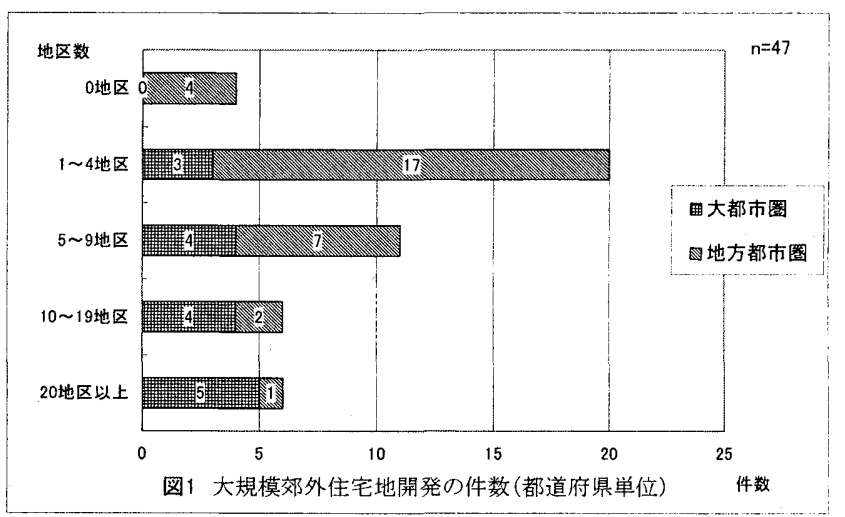

次に、地方別に開発件数をみてみると、関東地方が全体の 4 割近 くを占めていることがわかる。次いで近畿が多く、北海道・東北・ 中部・中国四国・九州の開発件数はほぼ等しい。面積や人口に比し て中部の件数が少ないことも明らかとなった。

一方で、新住事業の開発件数は、北海道 9 件、東北 3 件、関東 6 件、中部 2 件、近畿 19 件、中国 5 件、九州 5 件となっており、近 畿が最も多く、北海道・九州にも比較的多い。また、中部では少な く、四国では 1 件も行われていない。(図 2)

新住事業が行われたのは 19 都道府県で、残りの 30 県では新住事 業は行われていない。都道府県別にみると、兵庫県が 10 件で最も 多く、北海道 9 件、大阪府 7 件と続いている。以上から、新住事業 の開発地域は偏在しており、近畿地方と北海道に多いことが指摘で きる。また、人口 10 万人あたりの開発件数をみてみると、北海道 
が最も多く、近畿地方が続いている。北海道は道内の主要都市（札 幌、旭川、函館、釧路、帯広) で満遍なく 1 件ずつ開発されており、 近畿圈では神戸市での開発が 8 件注 17) と多い。(表 1)

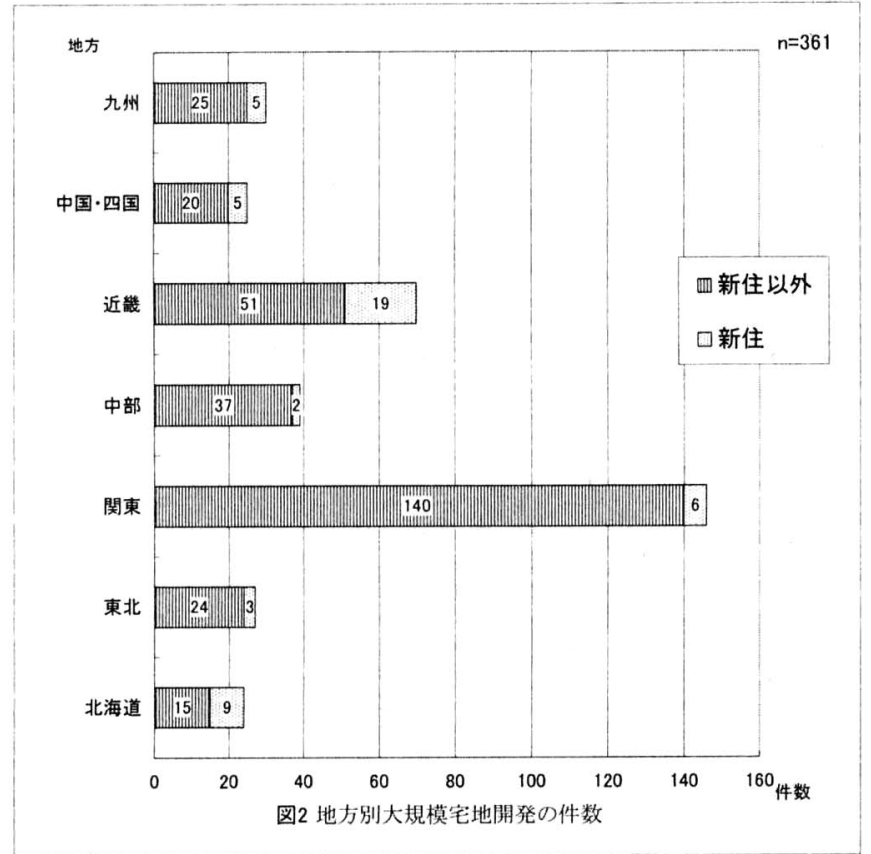

表1人口当たりの開発件数

\begin{tabular}{|c|c|c|c|c|c|}
\hline & $\begin{array}{c}\text { 人口 } \\
\text { (10万人) }\end{array}$ & $\begin{array}{c}\text { 大規模 } \\
\text { 開発 }\end{array}$ & $\begin{array}{l}\text { 人口10万人 } \\
\text { 当たり大規 } \\
\text { 模開発件数 }\end{array}$ & $\begin{array}{l}\text { 新住 } \\
\text { 件数 }\end{array}$ & $\begin{array}{l}\text { 人口10万 } \\
\text { 人当たり } \\
\text { 新住件数 }\end{array}$ \\
\hline 北海道 & 56.3 & 24 & 0.4263 & 9 & 0.1599 \\
\hline 東北 & 97.1 & 27 & 0.2781 & 3 & 0.0309 \\
\hline 関東 & 408.4 & 146 & 0.3575 & 6 & 0.0147 \\
\hline 中部 & 234.3 & 39 & 0.1665 & 2 & 0.0085 \\
\hline 近畿 & 206.5 & 70 & 0.3390 & 19 & 0.0920 \\
\hline 中国-四国 & 118.3 & 25 & 0.2113 & 5 & 0.0423 \\
\hline 九州 & 147.6 & 30 & 0.2033 & 5 & 0.0339 \\
\hline
\end{tabular}

\section{2-3. 開発主体}

大規模開発の事業主体についてみると、旧住宅公団やその後継組 織(ここでは公団としている)が 180 件を開発しており、全体の $48 \%$ を占めている。次いで都道府県住宅供給公社が 75 件 $(20 \%)$ 、市町 村 50 件、都道府県 32 件の順となっている。このことから、わが国 の大規模開発の主力は、公団・公社を中心とする公的開発主体であ ったといえる。

開発主体について、各都市圈注 18$)$ の特色をみていくと、首都圈で 最も開発が多いのが公団系の 105 件であり、中京圈では公団系は 17 件となっている。これは、公団、特に日本住宅公団及び宅地開発公 団が三大都市圈を中心に大規模開発をすすめてきたためであると考 えられる。一方、地方都市圈における大規模開発は、住宅供給公社 や地方自治体によって行われていたことが分かる。ここから、公団 による開発が期待できない地域において、住宅供給公社や地方自治 体が主導的な役割を果たしていたものと思われる。

このうち新住事業の開発は、最も多いのが市町村（新住事業の場 合は市のみ)の 17 件で、次いで都道府県 13 件、公社 11 件である。 大規模開発全体においては公団が中心であるのに対して、新住事業 では地方自治体によるものが多い。逆に、地方自治体による大規模 開発に占める新住事業の割合は、都道府県約 $40 \%$ 、市町村約 $34 \%$ となっており、高いといえる。ここから、新住事業の特質の 1 つは 地方自治体による開発が多いということがいえる。（表 2)

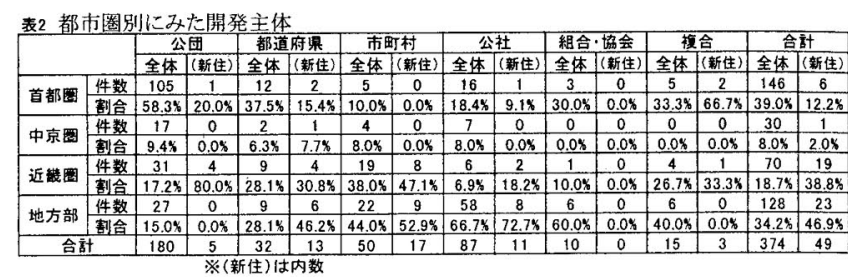

\section{2-4. 開発手法}

大規模開発の開発手法は、区画整理 $(47.3 \%)$ が最も多く、次い で公的一般 $(27.7 \%) 、$ 新住事業 (13.3\%) の順となっている。

次に、都市圈別に開発手法をみてみると、首都圈・中京圈・近畿 圈ではいずれも区画整理が最も多い。但し、近畿では新住事業の割 合 (27.1\%) も高い。地方部では公的一般 (44\%) が最も多いが、 北海道については図 2 からも明らかなように新住の割合 (37.5\%) が高い。なお、新住事業の割合が最も高いのは近畿圈である。これ に関して住田は、主に新住事業の分布に注目して「大規模宅地開発 手法のうち、施行者がどの手法を採用するかは、その地域の土地の 形状、用途、開発状況、地域住民の意向などに左右されるのはもち ろんであるが、とくに新住法の場合、全面買収方式であるため土地 の全面買収が可能かどうか、そのほうが得策かどうかの判断に大き く動かされることになる。」注19〉としている。（表 3） 表3 都市圏別にみた開発手法

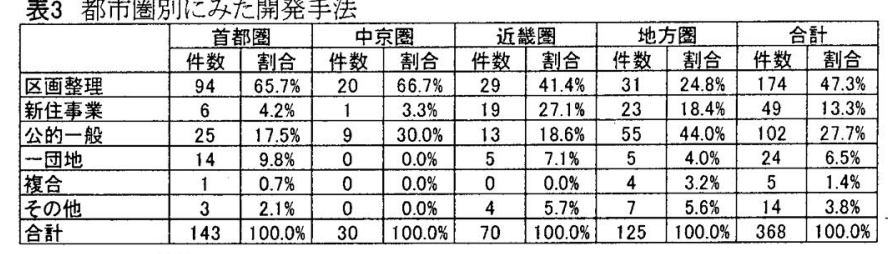

\section{2-5. 開発時期}

大規模開発の事業開始年代をみていくと、1970 年〜 74 年に開発 が開始された件数が最も多く（81 件）、次いで 1965 年〜 69 年 $(68$ 件）が続いている。つまり、1965 年から 1974 年にかけての 10 年 間に、計画面積が 50 ha を超える大規模郊外住宅団地の約 $40 \%$ が事 業を開始している。また、1985 年以降は開発件数が半減してしまっ ている。以上のことから、大規模開発は 1964 年までを開始期、1965 〜 74 年を発展期、1975 84 年を安定期、1985 年以降を収束期と位 置づけることができる。(図 3 )

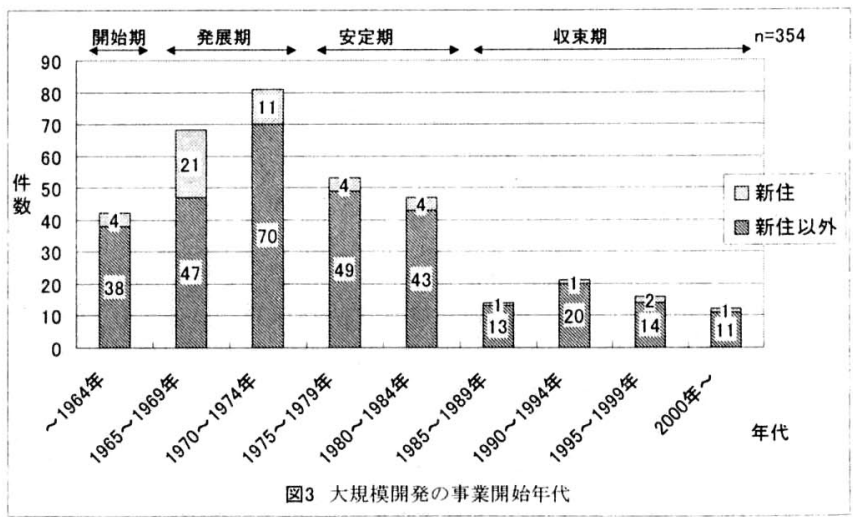

都市圈別に事業開始年代の特徵をみていくと、1964 年までに開発が 始まった地区は首都圈や近畿圈で多く、地方都市圈では少ないこと がわかる。

次に新住事業に着目してみると、1964 年から 1969 年までの 6 年 間に 25 件あり、全体の $51 \%$ を占めている。（図 4) その後 1970 年 
代までは開発が続いていたことがわかるが、1980 年代以降は開発開 始件数が一気に減少している。1990 年代以降に開発が開始された地 区が 4 件あるが、このうち、2000 年以降は 1 地区のみである。こ こからは、新住事業は新住法が施行された 1964 年から発展期にか けて一気に事業が開始され、安定期以降は件数が減少し、現在では ほとんど新規の開発は行われていないことが明らかである。また、 1000ha を超える規模の 4 件は全て発展期に開発が始まっている(図 4-A）。一方で安定期・収束期に開発が開始された新住団地は、全て が 500ha 未満である (図 4-B)。

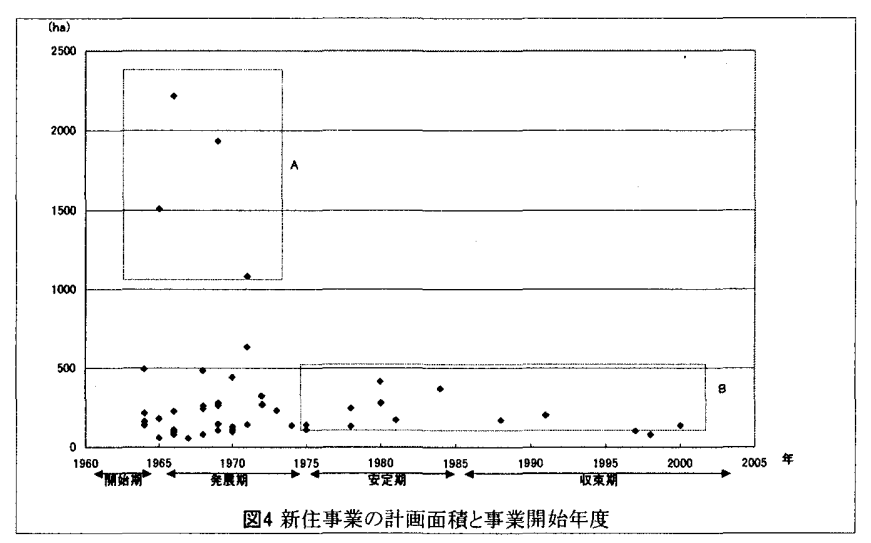

\section{2-6. 開発規模}

大規模開発で注計画人口は 5000 人以上 1 万人未満 $(34 \%)$ が最 も多く、次いで 1 万人以上 2 万人未満が多い。まとめると、5000 人以上 2 万人未満が全体の 6 割以上の件数を占めている。また、計 画人口が 10 万人を超える超大規模ニュータウンは、件数では 6 件 しかないが、この 6 件の計画人口の合計は 100 万人を超えている。 これは大規模開発全体の計画人口（約 600 万人）の 6 分の 1 に相当 する。

地方別に計画人口の規模を区分してみると以下のようになる。特 に近畿と関東において計画人口の多い郊外住宅団地の割合が高いと いら特徵が現れている。(表 4)

\section{表4 計画人口}

\begin{tabular}{|c|c|c|c|c|c|c|c|}
\hline & 5000人未满 & 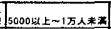 & 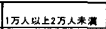 & 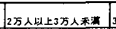 & 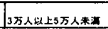 & 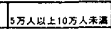 & 10 万人以上 \\
\hline 北海道 & 2 & 5 & 10 & 5 & 2 & 0 & 0 \\
\hline 東北 & 4 & 17 & 9 & 3 & 0 & 0 & 0 \\
\hline 関東 & 11 & 45 & 40 & 27 & 12 & 7 & 3 \\
\hline 中部 & 5 & 16 & 14 & 2 & 1 & 1 & 0 \\
\hline 近畿 & 4 & 19 & 20 & 5 & 17 & 2 & 3 \\
\hline 中国·四国 & 8 & 12 & 3 & 1 & 1 & 0 & 0 \\
\hline 九州 & 3 & 15 & 12 & 5 & 0 & 0 & 0 \\
\hline 全国 & 37 & 129 & 108 & 48 & 33 & 10 & 6 \\
\hline 新住 (内数) & 0 & 5 & 19 & 10 & 7 & 4 & 4 \\
\hline
\end{tabular}

大規模開発で最も規模が大きいものは南多摩地区で、計画面積は $2225.6 \mathrm{ha}$ 、計画人口は 28 万 2 千人であり、この開発は新住事業で 行われている。これ以外に計画人口が 10 万人を超える大規模開発 は 5 件あるが、このうちの 3 件も新住事業であり、2 件は区画整理 である。

次に計画面積別に見てみると以下のようになる。全体の $45 \%$ が $100 \mathrm{ha}$ 末満であり、200ha 未満でみると全体の約 4 分の 3 が該当す る。一方で、300ha 以上の巨大郊外住宅団地は全体の 1 割強となっ ている。都市圈別に計画面積を見てみると、近畿圈で大規模な開発 の比率が高いという特色が見られる。ここから、近畿圈では $50 \mathrm{ha}$ 〜100ha 程度の一住区団地が少なく、ニュー「タウン」レベルの開 発が中心であった。

新住事業に着目してみると、100ha 未満が 7 件であり、300ha 以
上が 11 件ある。なお、300ha 以上の 11 件のうち、4 件は $1000 \mathrm{ha}$ を超える計画面積である。他の大規模郊開発と比較すると、計画面 積の大きな地区が新住では大きな割合を占めているといえる。また、 大規模開発に占める新住事業の割合は約 $13 \%$ であるが、計画面積が $300 \mathrm{ha}$ を超える地区については、新住団地の占める割合が約 $27 \%$ と 非常に大きくなっている。（表 5)

\begin{tabular}{|c|c|c|c|c|c|c|c|c|c|c|}
\hline & \multicolumn{2}{|c|}{ 首都圈 } & \multicolumn{2}{|c|}{ 中京圈 } & \multicolumn{2}{|c|}{ 近畿圈 } & \multicolumn{2}{|c|}{ 地方部 } & \multicolumn{2}{|c|}{ 合計 } \\
\hline & 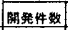 & (新住) & 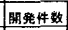 & (新住) & 閶器件政 & (新住) & $\mid$ & (新住) & 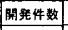 & (新住) \\
\hline 50ha以上100ha未満 & 72 & 0 & 17 & 0 & 22 & 2 & 58 & 5 & 169 & 7 \\
\hline 100ha以上 $150 \mathrm{ha}$ 未満 & 32 & 1 & 6 & 0 & 16 & 5 & 26 & 8 & 80 & 14 \\
\hline 150ha以上200ha末満 & 14 & 0 & 4 & 0 & 8 & 2 & 16 & 4 & 42 & 6 \\
\hline 200ha以上300ha末満 & 11 & 2 & 0 & 0 & 13 & 4 & 18 & 5 & 42 & 11 \\
\hline 300ha以上 & 17 & 3 & 3 & 1 & 11 & 6 & 10 & 1 & 41 & 11 \\
\hline 合計 & 146 & 6 & 30 & 1 & 70 & 19 & 128 & 23 & 374 & 49 \\
\hline
\end{tabular}

※(新住)は内数

\section{3. 新住事業の特質}

新住法は大規模開発に関する手法のなかでも、特に計画性が強い と思われる。そこで、本章では新住事業の計画性の強さを明らかと するために、開発理由や土地利用計画等の特性について検討する。

\section{3-1. 開発理由}

新住事業の開発理由を、新住事業の計画書等をもとにして分類し た。都市部のスプロールを防止することや、人口増加圧力などから 発生する住宅地建設の必要性を理由としている「スプロール防止・ 住宅地供給の緊急的必要性」が 31 件と最も多く、新産業都市建設 に伴うものや空港・官公庁建設などを理由とするものが 10 地区、 埋立事業に伴う土砂採取による跡地利用が 8 地区ある。このうち、 土砂採取による跡地利用の多くはスプロール防止も目的に含まれて いるといえる。

地方ごとの特色をみてみると、埋立事業を理由としているものが 近畿・中国に集中している。特に近畿については 6 件中 5 件が神戸 市が事業を行ったものである。（表 6)

\begin{tabular}{|c|c|c|c|c|}
\hline & $\begin{array}{c}\text { スプロール防止·住宅地供 } \\
\text { 給の緊急的必要性 }\end{array}$ & $\begin{array}{l}\text { 新産業都 } \\
\text { 市等建設 }\end{array}$ & 埋立事業 & 合計 \\
\hline 北海道 & 7 & 2 & 0 & 9 \\
\hline 東北 & 2 & 1 & 0 & 3 \\
\hline 関東 & 4 & 2 & 0 & 6 \\
\hline 中部 & 1 & 1 & 0 & 2 \\
\hline 近畿 & 11 & 2 & 6 & 19 \\
\hline 中国 & 3 & 0 & 2 & 5 \\
\hline 九州 & 3 & 2 & 0 & 5 \\
\hline 合計 & 31 & 10 & 8 & 49 \\
\hline
\end{tabular}

\section{3-2. 鉄道アクセスの整備}

公共交通の整備、特に鉄道のアクセスについて見てみると、12 地 区において新住団地内に鉄道が新たに敷設されている。これは、新 住団地建設に付随して鉄道を建設する場合、新住団地内と外部の 1 駅の間については国の補助金が出ていたことと関連する。新住団地 の公共性の強さ、計画性の強さが新住団地における鉄道アクセスの 整備につながっているといえる。(表 7)

\section{3-3.土地利用計画}

新住団地は土地利用計画の特色からいくつかの分類が可能である 新住団地は本来的には住宅団地に特化したものであったが、1980 年代以降に計画が行われたものを中心に、特定業務施設地域が設け られている地区や、大学などの学園施設が建設されている地域がみ られる。また、新住団地の規模が大きい地区では、日用品買いまわ りのための近隣センターのみでなく、地区センター・中央センター などが建設されている。地区センターや中央センターなどでは、日 
用品買いまわりに限定せず、様々な都市機能が整備されており、こ れらの用途で用いられる用地の割合も大きくなっている。

新住団地の機能について、最も規模の大きなセンターをもとに区 分すると次のようになる。「独立都市型」は中央センターが設置され ているもの、「衛星都市型」は地区センターが設置されているもの、 「住宅団地型」は近隣センターのみが設置されているもの及びセン ターが設置されていないものである。（表 7)

土地利用計画から新住団地の特色をみてみると、住宅用地の割合 がほとんどの地区で最大となっている。住宅用地の割合が最も高い のが鶴山台地区の $70.9 \%$ 、最も低いのが神戸研究学園都市地区の $24.7 \%$ である。また、住宅用地の割合が $60 \%$ 以上の新住団地が 5 地 区あった一方で、30\%未満の新住団地も 2 地区ある。新住団地の土 地利用計画をみてみると、いくつかの特徵を捉えることができる。 住宅用地が $30 \%$ 未満の 2 地区では、いずれも計画地内に大学や私立 中学高校などの学園用地が確保されている。住宅用地が $60 \%$ を超え る所の多くでは、新産等の従業員用住宅を建設する役割を担ってい る。また、新住団地の建設理由のうち、新産業都市建設を理由とし てつくられた住宅団地 10 地区においては、土地利用計画に占める 住宅用地の割合がいずれも $40 \%$ を越えている。新住団地の計画面積 が大きな地区では、公益的施設として近隣センター（住区センター） 以外にも、都市機能を持たせる目的で地区センターや中央センター が計画されており、その分住宅用地の割合が低くなっている。また、 特定業務施設地区が置かれている新住団地では住宅用地の割合が低 くなっている。(図 5)

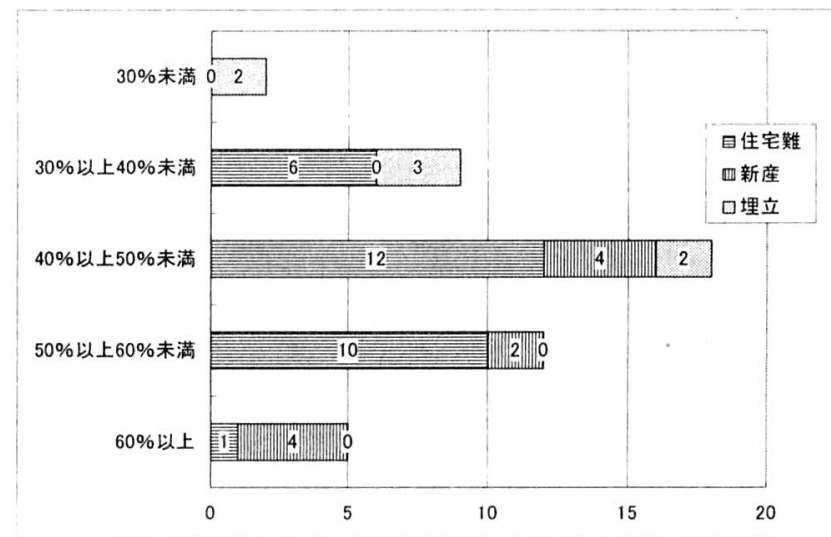

図5 新住団地に执ける土地利用計画に占める住宅用地の割合と新 住事業の開発理由

\section{3-4. 新住事業と土地収用}

新住法の特質のうち、ニュータウン開発における最大の武器は土 地収用を可能としている点であると言える。この点について新住法は 第 34 条4項「新住宅市街地開発事業につき都市計画法第 69 条の規 定により適用される土地収用法の規定により土地又は権利が収用さ れる場合において、権原により当該土地又は当該権利の目的である 土地に建築物その他の土地に定着する工作物を所有する者は、その 工作物の収用を請求することができる。」と規定している。

土地収用が可能であるということは、新住事業を実施するにあた って、土地買収における地権者之事業者の交涉が地権者有利とは限 らなくなるということが指摘できる。通常の買収であれば地権者が 土地の売却を決意しなければ絶対に先に進めない問題が、新住事業 においては事業者が所定の手続きを行い、公共性が認められる前提 において土地収用が可能である。では、実際に収用が行われたケー
スがどの程度あったのかについて検討する。

新住事業 49 地区のうち、実際に都道府県の収用委員会において 土地収用の裁決がなされたのが 24 地区である。このことから、新 住事業にお汀る収用権は、地権者への劦しのための道具ではなく、 実際に使用されている「公権力」であることがわかる。次に、実際 に収用委員会が土地収用の裁決を行った地区にはどのような特色が 見られたかを見てみると、件数が最も多いのは北捸地区で 151 件と 圧倒的に多く、次いで泉北丘陵地区が 25 件、千葉北部地区が 15 件、 南多摩地区が 13 件で続いている。この 4 つの地区に共通する特徵 として、いずれも $1000 \mathrm{ha}$ を超えるという開発規模の大きさと、事 業期間の長さが指摘できる注20)。

24 地区の地域的な偏りを見てみると、収用の裁決は三大都市圈と 北海道・中国で見られ、東北・九州では全く見られていない。新住 事業自体が地域的偏りを持っていることは先に指摘したが、それに 加えて新住法最大の特色とも言える土地収用についても実施に地域 的な偏りが見られる。(表 7)

\section{表新住宅淮地留登事業}

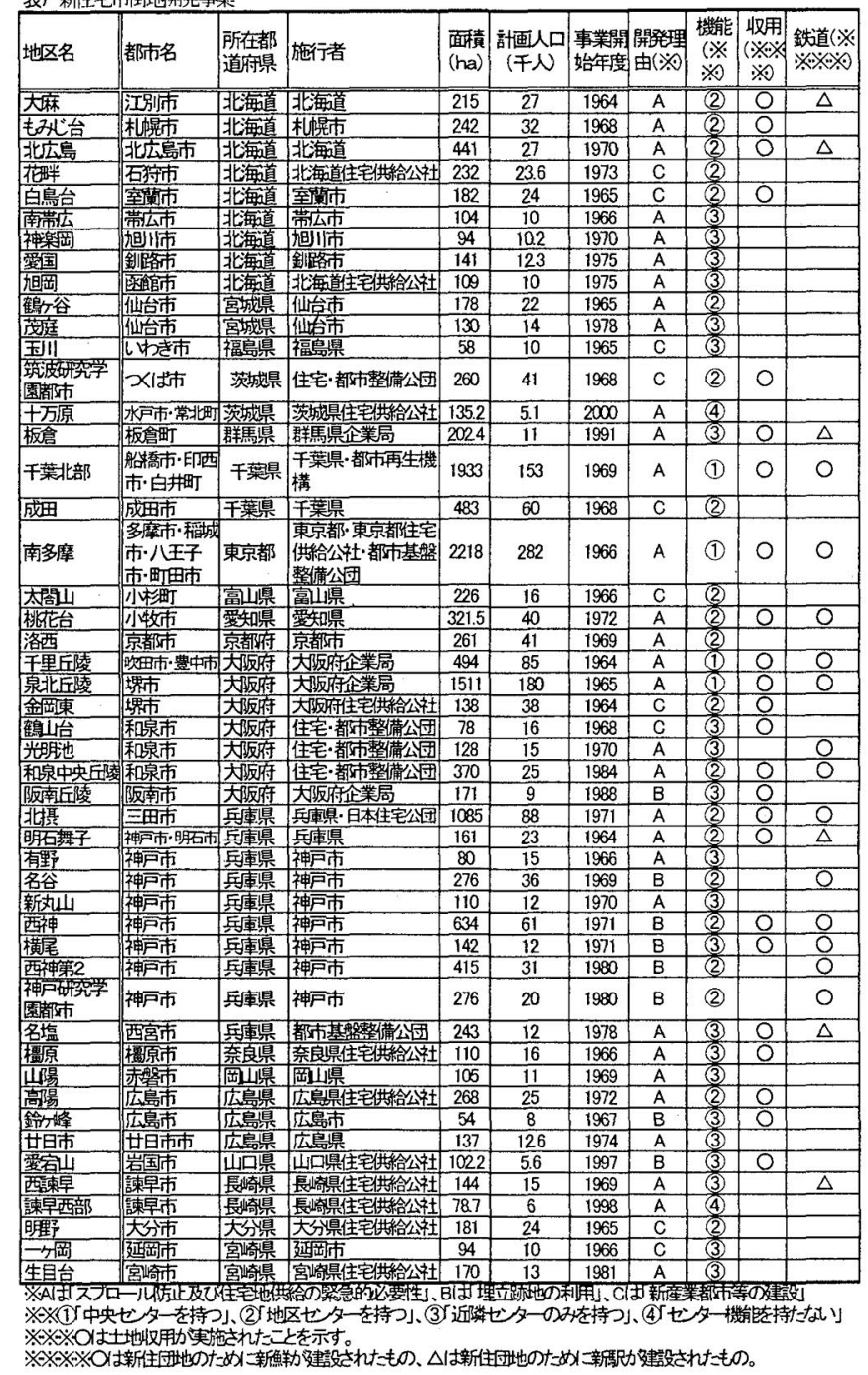

\section{4. 結論}

戦後の大規模開発は、三大都市圏を中心に全国各地で行われてい る。1960 年代から 70 年代にかけての開発圧力は、バブル期と比し ても強かった。今回調查対象とした大規模開発のうち、3 分の 2 以 上が 1979 年までに事業が開始されているという点で、戦後の大規 
模開発は 1960 年代から 70 年代にかけての時期が中心であったとい うことができる。また、開発の手法をみると、三大都市圈では区画 整理中心であったが、地方部では公的一般が多く、北海道では新住 が中心となっていた。

新住事業は全国 49 ケ所で行われたが、全体的な特徴として、大 規模開発全体の中でみても規模が大きな地区が多い。地域的な面で は、近畿地方で件数は多く開発規模も大きく、関東地方では件数は 少ないものの 1 地区あたりの開発規模が非常に大きいといら特色を 示しており、首都圈及び近畿圈の大規模開発において新住事業が大 きな位置を占めていたといえる。この背景には、首都圈及び近畿圈 では 1960 年代から 70 年代にかけて大規模な住宅地開発の必要性が 非常に高まっていたことと、それに対応するためには土地収用を行 ってでも計画的かつ良質の公的住宅地開発を行う必要があったこと が考えられる。そして、これらの条件に合致した大規模住宅地開発 の手法が新住法であったことが理由として挙げられる。

開発理由からみてみると、宅地不足の解消やスプロールの防止を 理由としているものが多い。土地利用計画については、住宅用地の 割合が $40 \%$ を超える地区が全体の 7 割を超えているという特徵も 明らかとなった。

新住事業の半数近くの地区で、土地収用の裁決がなされた案件が あった。特に事業期間が長く、計画面積の大きな新住事業において 収用の裁決が多い。この理由としては、用地の買収については地権 者と事業者の閒で交渉が行われる必要があり、十分な交渉が行われ た上でなければ土地収用を行うことは許されず、地権者と事業者の 交涉が長期化することによって、新住事業自体も長期化してしまい、 最後に収用権が行使されたことが考えられる。

本節の最初に述べたように、大規模郊外住宅団地は 1960 年代か ら 70 年代にかけて大量に供給されており、開発開始から $30 \sim 40$ 年 程度経過している地区が大量に存在している。これらの大規模郊外 住宅団地においては、集合住宅やセンター施設の改修や建替え、高 齢化への対応などが緊急の課題として既に浮上している。この点に ついては、大規模郊外住宅団地全体の課題であるが、特に新住事業 においてはその特質を活かすことによって、より良い居住環境の実 現が可能になるのではないかと考えられる。具体的には、新住事業 は、土地区画整理事業などの他の事業手法と比べて計画性が非常に 強いという特質を持っている。この点は、新住事業における公共・ 公益施設の充実とも関わっており、土地利用が長期間にわたって固 定化している要因ともなっているが、反面、他の事業手法に比べて 良好な住環境を維持しうる担保となっている。このような二面性を 考慮し、当初計画の理念やその有効性を見すえながら、原則的で柔 軟な対応をす心゙きである。土地の高度利用・有効活用にばかり重点 を置いたり、無計画に集合住宅の更新や用途変更などを行うのでは なく、居住者全体の生活の質を向上させるような形でこれらの課題 に対応するべきであると思われる。

\section{参考文献}

1）住田昌二編「日本のニュータウン開発一千里ニュータウンの地域計画学的 研究」都市文化社, 1984

2）片寄俊秀「ニュータウンの建設過程に関する研究」長崎総合科学大学, 1977
3）小川知弘・堀田祐三子・塩崎賢明「ニュータウンにおける近隣的商業施設 に関する研究一新住宅市街地開発事業に上る住宅団地を事例として一」日本 建築学会計画系論文集第 614 号, pp205-211, 2007.4

4)三好唐隆「郊外ニュータウンの持続的発展方策に関する基礎的研究一兵庫 県三苖市のニュータウンと既成市街地の比較分析を通して」学位論文 (大阪 大学),2004

5）大阪府企業局「千里ニュータゥンの建設」大阪府

6）宅地開発協会編「宅地ハンドブック 2003 年版」日本宅地開発協会,2004

7）都市計画協会「都市計画年報 2006 年版」，2007

8）新版宅地開発便覧編集委員会編「新版宅地開発便覽」鹿島出版会, 1985

9）高橋賢一「連合都市圈の計画学ーニュータウン開発と広域連携」鹿島出版 会, 1998

10）日本建築学会都市計画委員会編（1993）「成熟過程のニュータウン」日 本建築学会 1993 年都市計画部門研究協議会資料

11）全国収用委員会連絡協議会「土地収用裁決集」第一法規・ぎょうせ い,1969·2004

注

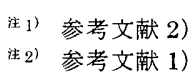

i注）参考文献 9)

注4) 多摩ニュータウン、港北ニュータウン、千葉ニュータウンの各ニュータウ ンを取り扱っている。

注 5) 参考文献 4)

注6)参考文献 3)

注7)参考文献 8)

注 8) 参考文献 6)

注9)鈴ケ峯地区の54haが最小である。

注 10) 千里ニュータウンのうち、豊中市内の 4 つの住区と吹田市内のうち桃山 台・竹見台の 2 つ住区が新住事業として開発されている。吹田市内の残 りの 6 住区は一団地の住宅施設として開発されている。

新 11 住法施行時には 2 年以内であったが、1986 年の改正で 5 年以内に延長 された。

注 12 分講から建築までの制限期間が 2 年から 4 年に延長された。

法 $1^{\prime}$ 都市再生機構は、都市基盤整備公団を前身としている。なお、都市基盤 整備公団は住宅・都市整備公団及び地域開発公団の宅地開発部門を合併し て発足した組織である。また、住宅・都市整備公団は日本住宅公団と宅地 開発公団が合併した組織である。なお、本論においては、都市基盤整備公 団、住宅・都市整備公団、地域開発公団、日本住宅公団、宅地開発公団に よる大規模郊外住宅地開発も都市再生機構として取り扱っている。

注14’一部の住宅地開発については、開発主体や計画人口などが不明瞭なもの むあった。

${ }^{15)}$ 北海道の人口は約 580 万人、兵庫県の人口が約 560 万人である。(2006 年 4 月末現在

注 ${ }^{16)}$ 大都市圈は、首都圈・中京圈・近畿圈に属する都府県とした。

注 17) 明石舞子地区(神戸市及び明石市) を含む。

注 18 首都圈は東京都・神奈川県・千葉県・埼玉県・栃木県・群馬県・茨城県 の 1 都 6 県、中京圈は愛知県・ 三重県・岐阜県の 3 県、近畿圈は大阪府・ 京都府・兵庫県・奈良県・和歌山県・滋賀県の 2 付 4 県、地方都市圈は首 都圈・中京圏・近畿圏以外の道県とした。

注 19! 参考文献 1)

注 $20^{\prime}$ 北摂地区の計画面積は 1101 ha、事業期間は 2007 年 3 月末現在も継続中 であるが、現在までで 36 年間となっている。泉北丘陵地区の計画面積は $1511 \mathrm{ha}$ 、事業機関は17 年間となっている。千葉北部地区の計画面積は約 1933ha、事業期間は 2007 年 3 月末現在も継続中であるが、現在までで 38 年間となっている。南多摩地区の計画面積は約 $2226 \mathrm{ha}$ 、事業期間は 29 年 間である。

(2007年 5 月 10 日原稿受理, 2007 年 9 月 25 日採用決定) 